\title{
Post-fire resprouting strategies of woody vegetation in the Brazilian savanna
}

\author{
Fabiane Furlaneto Souchie ${ }^{1 *}$, Jose Roberto Rodrigues Pinto ${ }^{1}$, Eddie Lenza ${ }^{2}$, Letícia Gomes ${ }^{3}$, \\ Leonardo Maracahipes-Santos ${ }^{4}$ and Divino Vicente Silvério ${ }^{4}$
}

Received: October 27, 2016

Accepted: March 23, 2017

\begin{abstract}
Post-fire response by vegetation may reflect the severity of the damage suffered, but we still know little about the species-specific nature of responses to fire or their predictors. Here, we evaluated 26 woody species before and after a fire event in an Cerrado sensu stricto area (typical Brazilian savanna-type) in order to evaluate mortality rates and the type of resprouting (epigeal, hypogeal or epigeal + hypogeal). We evaluated the relative importance of stem diameter, height, and bark thickness as predictors of the type of post-fire resprouting, using a sequential logistic regression model (SLRM). Mortality was $4 \%$, while epigeal resprouting was recorded in $57 \%$ of the individuals, hypogeal resprouting was recorded in $24 \%$, and epigeal + hypogeal resprouting in $15 \%$. Our SLRM analysis indicated that bark thickness, followed by stem diameter, were the best predictors of the type of resprouting. There was a greater than $60 \%$ probability that individuals with bark thicker than $1.6 \mathrm{~cm}$ resprouted only epigeally. Our results confirm the resistance (low mortality) and resilience (high resprouting capacity) of the woody vegetation of the Cerrado sensu stricto to fire, and that thick bark is an effective protection against fire damage.
\end{abstract}

Keywords: bark thickness, Cerrado sensu stricto, disturbance, fire, resilience

\section{Introduction}

Fire is an important modeling agent of the vegetation of savanna formations (Bowman et al. 2009; Lehmann et al. 2014). As a selective pressure, fire favors the evolution of species with morphological adaptations that confer resistance to fire and/or the ability to recover (resilience), which ensure that individuals are more likely to survive (Hoffmann et al. 2009; Keeley et al. 2011; Dantas \& Pausas 2013). These adaptations include a thick and corticated rhytidome, which provides the vascular cambium with greater thermal protection (Miranda et al. 2002; Dantas \& Pausas 2013; Pausas 2014), and protects the meristematic tissues that enable the plant to resprouts in response to a fire event (Clarke et al. 2013; Charles-Dominique et al. 2015). Other adaptations include a greater investment in root biomass (Hoffmann \& Franco 2003; Oliveira et al. 2005; Charles-Dominique et al. 2015) and an increased capacity for the underground storage of carbohydrates (Miranda et al. 2002; Hoffmann et al. 2004; Clarke et al. 2013), which provide the energetic resources for post-fire recovery (Clarke et al. 2013).

In spite of these adaptations, a fire event always results in some damage to the trees, ranging from the loss of leaves, resulting from exposure to hot air, to the death of the individual (Bond \& Midgley 2001; Miranda et al. 2009).

\footnotetext{
${ }^{1}$ Faculdade de Tecnologia - Programa de Pós-Graduação em Ciências Florestais, Universidade de Brasília, P.O. Box. 04457, Campus Darcy Ribeiro, 70910-900, Brasília, DF, Brazil

${ }^{2}$ Programa de Pós-Graduação em Ecologia e Conservação, Universidade do Estado de Mato Grosso, Campus de Nova Xavantina, P.O. Box. 08, 78.690-000, Nova Xavantina, MT, Brazil

${ }^{3}$ Programa de Pós-Graduação em Ecologia, Universidade de Brasília, Campus Darcy Ribeiro, 70919-970, Brasília, DF, Brazil

${ }^{4}$ Instituto de Pesquisa Ambiental da Amazônia, Rua Horizontina 104, 78640-000, Canarana, MT, Brazil

* Corresponding author: fabianefsouchie@gmail.com
} 
In general, the post-fire resprouting response will depend on the part of the plant that survives the fire (Clarke et al. 2013). For the assessment of post-fire resprouting, then, the severity of fire damage to a tree can be classified as: (a) slight, when resprouting occurs exclusively in the crown (epigeal); (b) moderate, when simultaneous resprouting occurs in the crown and base of the tree (epigeal + hypogeal); (c) severe, when topkilling occurs, and resprouting is observed only at the base of the stem (hypogeal); and (d) permanent, when death occurs (Medeiros \& Miranda 2008; Moreira et al. 2008). Less severe fire damage has been observed in species with thicker bark (Hoffmann et al. 2009; Moreira et al. 2007) and larger-sized (in terms of height and stem diameter) individuals (Coutinho 1990; Mistry 1998; Sato et al. 2010; Ribeiro et al. 2012). Less intense fires are also associated with reduced fire damage (Hoffmann \& Solbrig 2003; Cirne \& Miranda 2008; Hoffmann et al. 2009).

While a number of studies have focused on the effects of fire on the vegetation of the Brazilian savanna (Hoffmann \& Solbrig 2003; Medeiros \& Miranda 2005; 2008; Sartorelli et al. 2007; Vale \& Lopes 2010), few insights have been provided into the post-fire resprouting strategies of the woody vegetation (Coutinho 1990; Medeiros \& Miranda 2005; Hoffmann et al. 2009; Ribeiro et al. 2012). We still know little about the intrinsic response of each species and the morphological features that best account for the differences among species in the type of post-fire resprouting. Given this, we quantified tree mortality and the three different types of resprouting (epigeal, hypogeal and epigeal + hypogeal) in native woody species in an area of Cerrado sensu stricto before and after a non-prescribed fire event.

\section{Materials and methods}

\section{Study area}

The study was conducted in the Bacaba Municipal Park ( $\left.14^{\circ} 41^{\prime} 09^{\prime \prime} S, 52^{\circ} 20^{\prime} 09^{\prime \prime} \mathrm{W}\right)$, a protected area of nearly 500 ha located in Nova Xavantina, in eastern Mato Grosso state, Brazil. The predominant vegetation physiognomy found in the park is the Cerrado sensu stricto (Marimon-Junior \& Haridasan 2005), the typical savanna vegetation in Brazil (Ribeiro \& Walter 2008). The climate is Aw in Köppen's classification system, with dry winters between April and September, and rainy summers between October and March (Silva et al. 2008). The soils are predominantly dystrophic, alic, deep, well drained and with medium granulation (RADAMBRASIL 1981), with a low $\mathrm{pH}(<5)$, low calcium and magnesium concentrations, but high concentrations of exchangeable aluminum (Marimon-Junior \& Haridasan 2005).

Bacaba Municipal Park had been protected from fire for more than five years when, on September $9^{\text {th }} 2008$, fire consumed $95 \%$ of its total area. The fire started outside the park, and encroached its area at around 13:00 h, with flames of up to $5 \mathrm{~m}$ in height, which reached the crowns of most trees (Silvério et al. 2015). At this time, relative humidity in the park was $41 \%$, air temperature was $29^{\circ} \mathrm{C}$ $\left(17-40^{\circ} \mathrm{C}\right.$ ), and mean wind speed was $21 \mathrm{~km} / \mathrm{h}$ (INMET 83319-MT). For the present study, we selected two adjacent sites representing the same vegetation type (Cerrado sensu stricto): (i) the burned site (BS), representing the vegetation affected by the fire, with a total area of nearly $2.5 \mathrm{ha}$, and (ii) the unburned site (US), with an area of nearly one hectare.

\section{Study species}

We studied 26 woody species in the BS and a subset of 12 of these species in the US (see, Tab. 1). These species belong to 15 families and together represent $62.5 \%$ of the community Importance Value (Gomes et al. 2011). Four months before the fire event, we selected the study individuals at the BS site, and a few days after the fire, in September 2008, we selected the individuals at the US site. We selected individuals for study based on three criteria: (1) individuals with evidences of reproductive organs (flower, fruits) and a stem diameter (30 $\mathrm{cm}$ above the ground) of at least $2 \mathrm{~cm}\left(\mathrm{SD}_{30 \mathrm{~cm}} \geq 2 \mathrm{~cm}\right)$; (2) a minimum distance of 10 $\mathrm{m}$ between individuals of the same species (to guarantee independence between individuals), and (3) good crown condition (leaves on all the branches) and no basal resprouts or fire scars. All the individuals selected for sampling were marked with numbered aluminum tags (attached to the stem by wire).

\section{Data collection}

Five months after the fire, in February 2009, we measured the height and $\mathrm{SD}_{30 \mathrm{~cm}}$ of the main stem of each plant found within each study area, and in the BS, we recorded the type of resprouting (classified as epigeal, hypogeal, epigeal + hypogeal) or mortality, and noted any evidence of resprouting in the individuals located within the US (Tab. 2). The response of the individuals to fire damage was also classified during the second assessment, in December 2010, 26 months after the fire (Fig. 1). During the third assessment, in January 2014, 64 months after the fire, we also recorded the mortality of the main stem in individuals located in the BS and US.

We measured the height of all individuals and the $\mathrm{SD}_{30 \mathrm{~cm}}$ of the main stem during all assessments (Felfili et al. 2005). Our height measurements however, are probably biased for some individuals of Davilla elliptica, which were strongly inclined. The length, rather than the height, was measured in this case. We also measured the thickness of the bark of a sample of 10-13 individuals per species using a 10-301-1002 model Haglöf Barktax bark gauge, which is designed to measure bark thickness directly. Bark thickness 
Fabiane Furlaneto Souchie, Jose Roberto Rodrigues Pinto, Eddie Lenza,

Letícia Gomes, Leonardo Maracahipes-Santos and Divino Vicente Silvério

Table 1. Number of individuals sampled on the burned (BS) and unburned site (UB) at the Bacaba Municipal Park, Mato Grosso, Brazil, types of response to fire of woody species in the BS ( $\mathrm{Re}=$ epigeal resprouting; $\mathrm{Reh}=$ epigeal + hypogeal resprouting; $\mathrm{Rh}=$ hypogeal resprouting; $\mathrm{Td}=\mathrm{dead}$ trees), and average \pm standard deviation for the three variables used as predictor of type of post-fire response (tree height in meter, stem diameter and bark thickness in centimeter). $\mathrm{Nbt}=$ number of individuals for which bark thickness was measured.

\begin{tabular}{|c|c|c|c|c|c|c|c|c|c|c|c|}
\hline \multirow{2}{*}{ Species } & \multirow{2}{*}{ Families } & \multicolumn{2}{|c|}{$\begin{array}{l}\text { Number of } \\
\text { individuals }\end{array}$} & \multicolumn{4}{|c|}{$\begin{array}{l}\text { Types of response } \\
\text { to fire in the BS }\end{array}$} & \multirow[t]{2}{*}{ Tree height } & \multirow{2}{*}{ Stem diameter } & \multirow[t]{2}{*}{ Nbt } & \multirow{2}{*}{$\begin{array}{c}\text { Bark } \\
\text { thickness }\end{array}$} \\
\hline & & BS & US & $\operatorname{Re}$ & Reh & $\mathbf{R h}$ & Td & & & & \\
\hline Anacardium occidentale & Anacardiaceae & 12 & 0 & 11 & 1 & & & $5.28 \pm 1.24$ & $18.23 \pm 4.71$ & 10 & $1.56 \pm 0.37$ \\
\hline Antonia ovata & Loganiaceae & 12 & 0 & & & 12 & & $3.39 \pm 0.57$ & $2.48 \pm 0.45$ & 13 & $0.25 \pm 0.11$ \\
\hline Aspidosperma macrocarpon & Apocynaceae & 12 & 0 & 11 & & 1 & & $5.19 \pm 0.78$ & $13.06 \pm 3.89$ & 10 & $1.59 \pm 0.29$ \\
\hline Aspidosperma tomentosum & Apocynaceae & 12 & 0 & 11 & 1 & & & $4.44 \pm 0.67$ & $9.87 \pm 2.10$ & 10 & $1.40 \pm 0.32$ \\
\hline Byrsonima coccolobifolia & Malpighiaceae & 23 & 12 & 16 & 4 & 2 & 1 & $4.77 \pm 1.08$ & $10.35 \pm 3.13$ & 10 & $1.27 \pm 0.21$ \\
\hline Byrsonima pachyphylla & Malpighiaceae & 24 & 12 & 20 & 2 & 1 & 1 & $2.84 \pm 0.46$ & $6.63 \pm 1.52$ & 10 & $0.95 \pm 0.32$ \\
\hline Davilla elliptica & Dilleniaceae & 28 & 12 & 7 & 15 & 4 & 2 & $2.99 \pm 0.62$ & $7.72 \pm 2.62$ & 10 & $1.18 \pm 0.22$ \\
\hline Dipteryx alata & Fabaceae & 12 & 0 & 12 & & & & $8.20 \pm 1.59$ & $27.34 \pm 7.31$ & 10 & $1.45 \pm 0.50$ \\
\hline Erythroxylum suberosum & Erythroxylaceae & 24 & 0 & 7 & 3 & 14 & & $2.43 \pm 0.76$ & $5.25 \pm 2.03$ & 11 & $1.33 \pm 0.23$ \\
\hline Eugenia aurata & Myrtaceae & 21 & 6 & 15 & 4 & & 2 & $3.22 \pm 0.76$ & $8.07 \pm 1.90$ & 12 & $1.59 \pm 0.24$ \\
\hline Heteropterys byrsonimifolia & Malpighiaceae & 12 & 0 & 8 & 3 & 1 & & $4.00 \pm 0.80$ & $11.37 \pm 4.69$ & 10 & $1.07 \pm 0.22$ \\
\hline Himatanthus obovatus & Apocynaceae & 20 & 0 & 5 & 1 & 14 & & $2.66 \pm 0.82$ & $4.04 \pm 2.22$ & 11 & $0.92 \pm 0.25$ \\
\hline Kielmeyera rubriflora & Calophyllaceae & 24 & 12 & 15 & 6 & 2 & 1 & $4.03 \pm 0.79$ & $9.73 \pm 3.84$ & 11 & $1.54 \pm 0.42$ \\
\hline Lafoensia pacari & Lythraceae & 24 & 0 & 11 & 6 & 7 & & $4.25 \pm 1.10$ & $8.99 \pm 2.90$ & 10 & $1.06 \pm 0.25$ \\
\hline Myrcia lanuginose & Myrtaceae & 12 & 13 & 1 & 1 & 10 & & $2.73 \pm 0.57$ & $5.87 \pm 1.72$ & 10 & $1.10 \pm 0.24$ \\
\hline Ouratea hexasperma & Ochnaceae & 12 & 12 & 10 & 2 & & & $3.41 \pm 0.51$ & $9.83 \pm 1.82$ & 10 & $1.47 \pm 0.25$ \\
\hline Ouratea spectabilis & Ochnaceae & 24 & 12 & 9 & 5 & 7 & 3 & $4.51 \pm 0.95$ & $10.75 \pm 3.03$ & 13 & $1.68 \pm 0.41$ \\
\hline Pseudobombax longiflorum & Malvaceae & 24 & 0 & 16 & 1 & 5 & 2 & $3.38 \pm 0.76$ & $10.26 \pm 2.42$ & 12 & $1.29 \pm 0.47$ \\
\hline Qualea grandiflora & Vochysiaceae & 23 & 12 & 11 & 7 & 5 & & $4.53 \pm 1.01$ & $11.36 \pm 4.13$ & 10 & $1.65 \pm 0.32$ \\
\hline Qualea multiflora & Vochysiaceae & 23 & 12 & 11 & 6 & 5 & 1 & $3.78 \pm 0.75$ & $8.54 \pm 2.23$ & 11 & $0.95 \pm 0.13$ \\
\hline Qualea parviflora & Vochysiaceae & 24 & 12 & 20 & & 2 & 2 & $5.31 \pm 0.96$ & $12.76 \pm 2.77$ & 10 & $1.32 \pm 0.20$ \\
\hline Roupala montana & Proteaceae & 12 & 12 & 3 & & 9 & & $4.71 \pm 2.15$ & $8.44 \pm 4.86$ & 10 & $1.33 \pm 0.18$ \\
\hline Salvertia convallariodora & Vochysiaceae & 12 & 0 & 12 & & & & $4.54 \pm 0.73$ & $12.52 \pm 1.60$ & 11 & $2.11 \pm 0.34$ \\
\hline Tachigali aurea & Fabaceae & 24 & 0 & 18 & & 2 & 4 & $5.66 \pm 0.94$ & $11.97 \pm 2.82$ & 10 & $1.42 \pm 0.34$ \\
\hline Tocoyena formosa & Rubiaceae & 23 & 0 & 6 & 5 & 12 & & $2.27 \pm 0.76$ & $3.59 \pm 1.27$ & 11 & $0.63 \pm 0.13$ \\
\hline Vatairea macrocarpa & Fabaceae & 12 & 0 & 10 & 2 & & & $6.52 \pm 0.96$ & $17.63 \pm 5.28$ & 10 & $1.48 \pm 0.35$ \\
\hline Grand total & 15 & 485 & 139 & 276 & 75 & 115 & 19 & $\mathbf{4 . 0 0} \pm 1.48$ & $\mathbf{1 0 . 0 0} \pm 5.00$ & 276 & $\mathbf{1 . 0} \pm 0.47$ \\
\hline
\end{tabular}

Table 2. Parameters of the logistic model's selection to assess the importance of variables included in the general model and the response probability of woody individuals to the occurrence of fire at the Bacaba Municipal Park, Mato Grosso, Brazil.

\begin{tabular}{|c|c|c|c|c|c|c|c|c|}
\hline $\mathbf{N}$ & Height & Bark thickness & $\mathbf{S D}_{30 \mathrm{~cm}}$ & Bark:SD & df & logLik & AICc & \multicolumn{1}{c|}{ Delta } \\
\hline 1 & & 3.170 & 0.511 & -0.319 & 6 & -488.509 & 989.195 & 0.000 \\
\hline 2 & -0.090 & 3.177 & 0.534 & -0.320 & 7 & -488.190 & 990.617 & 1.422 \\
\hline 3 & & 0.860 & 0.067 & & 5 & -501.038 & 1012.202 & 23.006 \\
\hline 4 & -0.098 & 0.850 & 0.090 & & 6 & -500.639 & 1013.455 & 24.259 \\
\hline 5 & & & 0.090 & & 4 & -505.202 & 1018.488 & 29.292 \\
\hline 6 & 0.157 & 1.090 & & & 5 & -504.666 & 1019.459 & 30.263 \\
\hline 7 & -0.110 & & 0.116 & & 5 & -504.699 & 1019.523 & 30.328 \\
\hline 8 & & & & & 4 & -511.484 & 1031.051 & 41.855 \\
\hline 9 & 0.239 & & & & 4 & -511.909 & 1031.902 & 42.706 \\
\hline 10 & & & & & 3 & -524.429 & 1054.907 & 65.712 \\
\hline
\end{tabular}

$\mathrm{N}=$ model number; $\mathrm{SD}_{30 \mathrm{~cm}}=$ stem diameter at $30 \mathrm{~cm}$ above soil; Bark:SD = ratio between bark thickness and the interaction with $\mathrm{SD}_{30 \mathrm{~cm}} ; \mathrm{df}=$ degree of freedom; logLik = logarithm of maximum likelihood; AICc = corrected Akaike information criterion; delta = delta of AICc, which is the difference between the AIC of the model 1 and the current model.

was measured four years after the fire event, and to avoid damaging the sample individuals, we selected individuals for measurement different from those used for the assessment of sprouting and mortality. We used these measurements to calculate the mean bark thickness per species (Tabs. 1, 2).

\section{Data analysis}

To assess general patterns of response to fire, we calculated the percentage of individuals of each species presenting each type of resprouting. We used a Pearson 


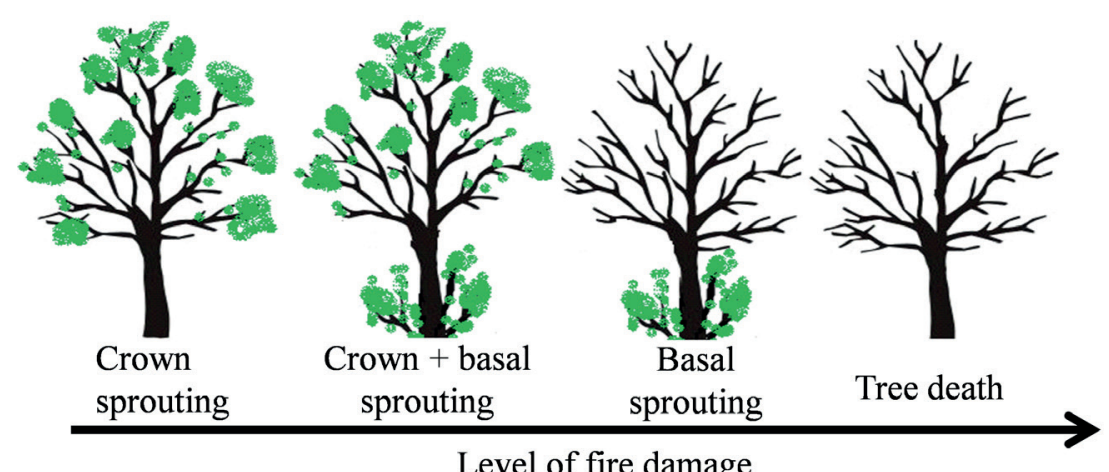

Level of fire damage

Figure 1. Types of response observed in woody individuals of the Brazilian Cerrado sensu stricto following a fire event (adapted from Moreira et al. 2008).

correlation analysis and a sequential logistic regression model to assess the influence of structural parameters on the type of resprouting. We first evaluated the degree of association between the percentage of individuals per species with basal sprouting (epigeal and epigeal + hypogeal groups) and mean bark thickness, stem diameter, and height (Fig. 2), using the Pearson correlation test (Zar 2010). We then applied a sequential logistic regression model to estimate the probability of a given type of resprouting as a function of: a) each tree height; b) each stem diameter $\left(\mathrm{SD}_{30 \mathrm{~cm}}\right)$; and c) average bark thickness by specie. Initially, we used the general model with the three variables, and we then assessed the contribution of each variable by comparing the models from which one of the variables was excluded. The best model was selected on the basis of the lowest Akaike Information Criterion score (Zuur et al. 2009). All analyses were run in the $\mathrm{R}$ software ( $\mathrm{R}$ Core Team 2016).

\section{Results}

\section{Types of response to fire}

Epigeal resprouts were the most common response to fire damage (57\% of individuals), followed by hypogeal resprouting ( $24 \%$ of individuals), and then epigeal + hypogeal resprouting (15\%), while tree mortality was $4 \%$ (Tab. 1). At a species level, however, more than one type of resprouting was recorded in most cases. For example, both epigeal and hypogeal resprouts were recorded in $73 \%$ of the study species, and all three types of resprouting were recorded in half (50\%) of the species. At one extreme, in the case of Dypterix alata and Salvertia convallariodora, for example, all (100\%) individuals presented epigeal resprouts, while at the opposite extreme, all three types of resprouting were recorded in Byrsonima coccolobifolia, Dipteryx elliptica, and Ouratea spectabilis. In the case of the 12 species studied in the US during the same period, no individuals presented basal resprouting, and tree mortality was just $2 \%$.

\section{Variables related to the type of response to fire}

The type of response of the species to fire was associated strongly with bark thickness, and there was a significant negative correlation $(r=-0.72 ; t=5.14 ; p<0.01)$ between the percentage of individuals of a species with a hypogeal response and its mean bark thickness (Fig. 2A). Similar patterns were recorded for stem diameter, i.e., the greater the $\mathrm{SD}_{30 \mathrm{~cm}}$, the smaller the number of basal sprouts $(\mathrm{r}=$ $-0.68 ; \mathrm{t}=4.60 ; p<0.01$ : Fig. $2 \mathrm{~B})$, and height $(\mathrm{r}=-0.58 ; \mathrm{t}$ $=3.56 ; p<0.01$ : Fig. 2C). The mean bark thickness of the different species also correlated significantly with their mean stem diameter $(r=0.64 ; t=4.11 ; p<0.05)$ and height $(\mathrm{r}=0.45 ; \mathrm{t}=2.47 ; p<0.05)$.

The best predictive model of the response of the woody plants to fire damage was the one that included bark thickness and stem diameter (Tab. 2). This model indicated a significant contribution of bark thickness and stem diameter to the determination of the specific type of

Table 3. Statistical summary of the variables that made up the best probability descriptor model of woody individuals being affected by fire at the Bacaba Municipal Park, Mato Grosso, Brazil.

\begin{tabular}{|c|c|c|c|c|} 
Variables & Model coefficient & Standard error & $\mathbf{T}$ & $\mathbf{P}$ \\
\hline Bark thickness $(\mathrm{cm})$ & 3.17 & 0.599 & 5.295 & $<0.001$ \\
\hline Stem diameter $(\mathrm{cm})$ & 0.511 & 0.095 & 5.385 & $<0.001$ \\
\hline Bark thickness $(\mathrm{cm})$ : Stem diameter $(\mathrm{cm})$ & -0.319 & 0.067 & -4.786 & $<0.001$ \\
\hline Hypogeal resprouting | Total mortality & 3.528 & 0.766 & 4.604 & $<0.001$ \\
\hline Total mortality | Epigeal resprouting & 3.795 & 0.77 & 4.927 & $<0.001$ \\
\hline Epigeal resprouting | Epigeal + hypogeal resprouting & 6.677 & 0.8 & 8.343 & $<0.001$ \\
\hline
\end{tabular}


Fabiane Furlaneto Souchie, Jose Roberto Rodrigues Pinto, Eddie Lenza,

Letícia Gomes, Leonardo Maracahipes-Santos and Divino Vicente Silvério

resprouting (Tab. 3). The pairwise comparisons between resprouts types indicated significant differences in all cases (Tab. 3). Analyzed on its own, height correlated significantly with the type of response, but did not contribute to any improvement in the adjustment of the model, so it was excluded from the final model (Tab. 3).

In the predictive model, we observed little variation in the type of response in individuals with thick bark $(\geq 1.6$ $\mathrm{cm}$ ), with a $60 \%$ probability of an epigeal response, even in the individuals with a smaller stem diameter (Fig. 3). There was much greater variation in individuals with thin bark $(\leq 1$ $\mathrm{cm}$ ), however, with an increased probability of an epigeal + hypogeal response in individuals with a stem diameter of more than $20 \mathrm{~cm}$. There was also a $20 \%$ decrease in the probability of a hypogeal response in individuals of species with thick bark (Fig. 3).

Some species exemplify these patterns clearly (Tab. 1). All the individuals of the species Dipteryx alata (mean stem diameter $=27.33 \pm 7.30 \mathrm{~cm}$ ) and Salvertia convallariodora (mean bark thickness $=2.10 \pm 0.33 \mathrm{~cm}$ ) presented only epigeal resprouting. By contrast, Antonia ovata, which had the thinnest bark of all the study species (mean bark thickness $=0.25 \pm 0.11 \mathrm{~cm}$ ) presented only a hypogeal response (top-kill in all individuals).

\section{Discussion}

The severity of the fire damage caused to the woody vegetation observed in this study can be classified as moderate to low based the high percentage of epigeal or epigeal + hypogeal resprouting (72\%), the lower hypogeal response (24\%), and the low mortality rate (4\%). Basal resprouting appears to be more frequent in areas with

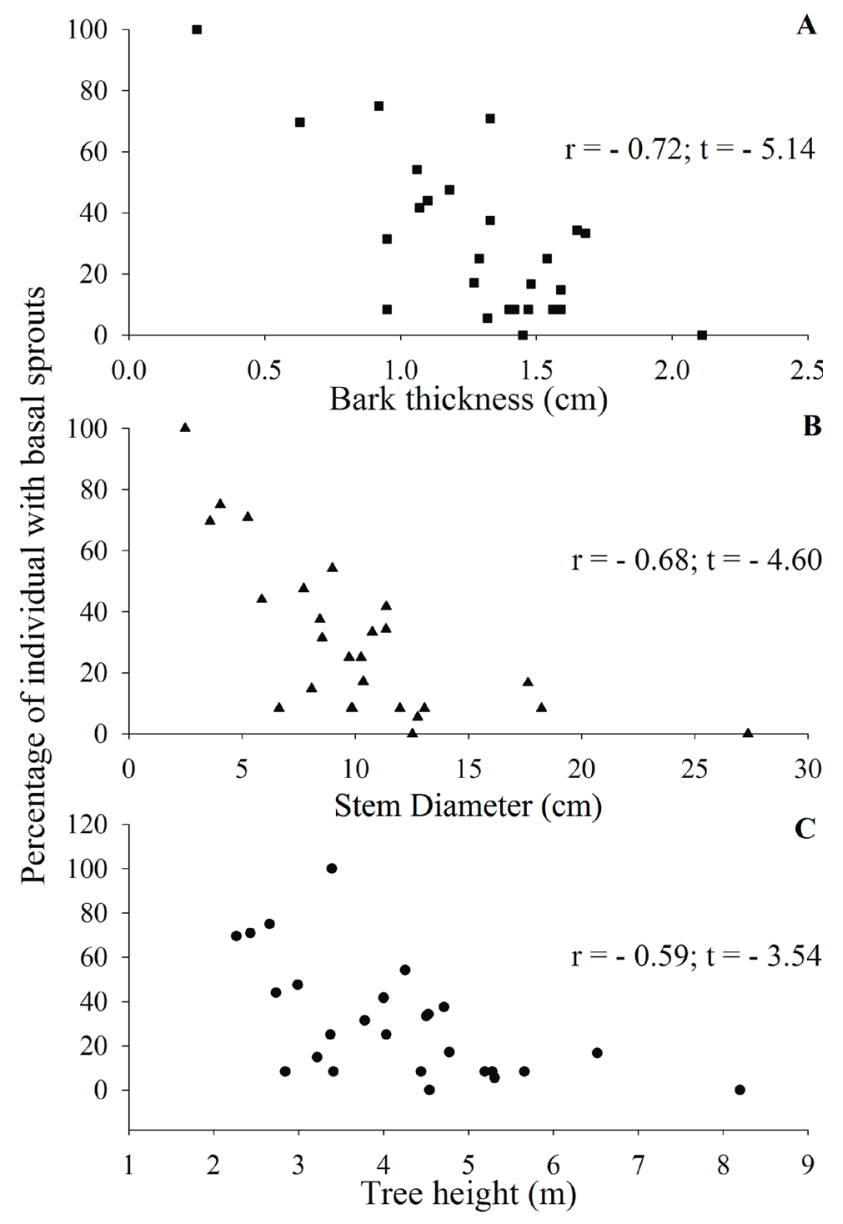

Figure 2. Percentage of the individuals of each species with basal sprouting as a function of (A) bark thickness average, (B) stem diameter average (30 $\mathrm{cm}$ above the ground), and $(\mathrm{C})$ tree height average by specie, in the Bacaba Municipal Park, Mato Grosso, Brazil.

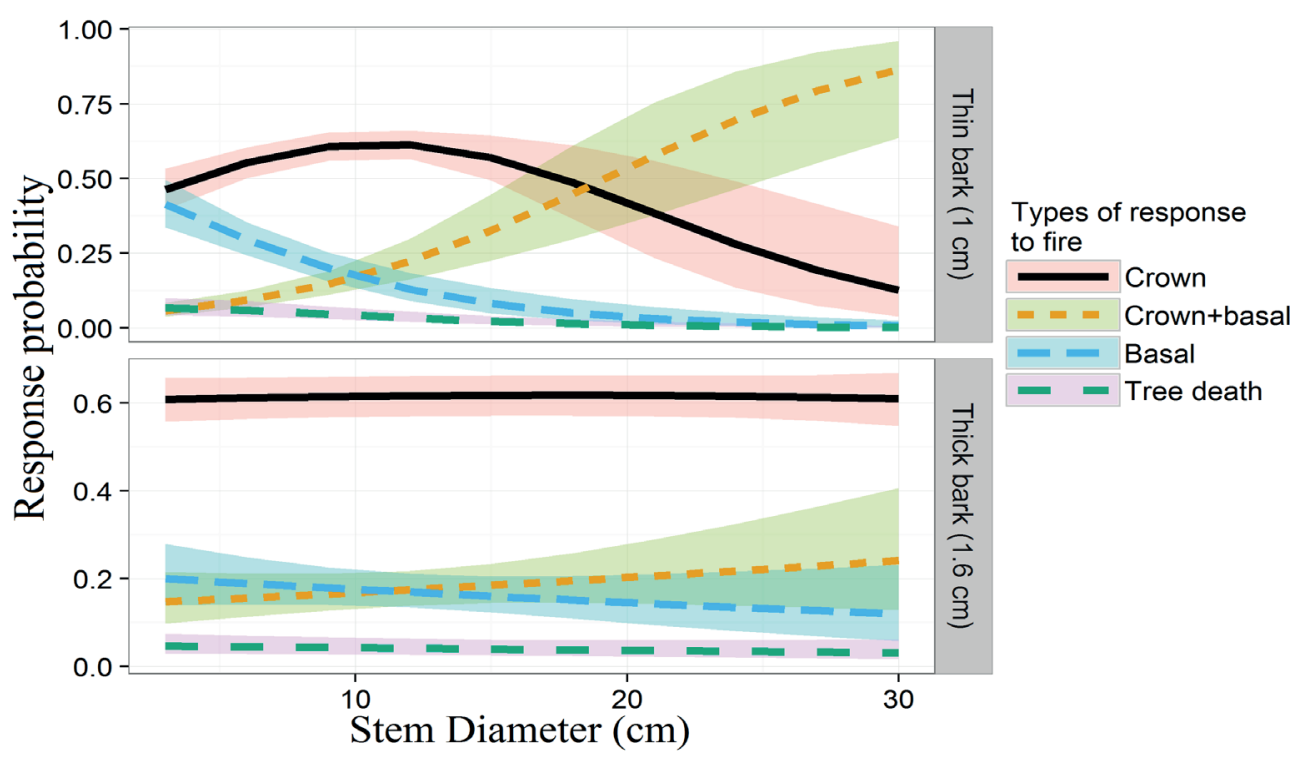

Figure 3. Influence of bark thickness and basal stem diameter $\left(\mathrm{SD}_{30 \mathrm{~cm}}\right)$ on the probability of different types of response to fire damage in native woody species in the Bacaba Municipal Park, Mato Grosso, Brazil. 
a higher frequency of disturbance by fire (Bellingham et al. 2000). In the Brazilian savanna, however, different vegetation types present considerable variation in their response to fire damage. In a study of the Cerrado sensu stricto in Mato Grosso, for example, Ribeiro et al. (2012) found epigeal response rates of between $85 \%$ and $91 \%$ in woody plants following fire events. By contrast, in a study of the effects of fires set in a Campo sujo (scrub grassland) physiognomy in the Brazilian Federal District, Medeiros \& Miranda (2008) recorded a $36 \%$ epigeal response rate, a $31 \%$ hypogeal rate, and an $11 \%$ epigeal + hypogeal rate, with a $22 \%$ mortality rate (we have adapted the categories used by these authors to correspond to the response categories used in the present study). This difference in comparison with the results of the present study may be related to contrasts in the composition and structure of the vegetation, and in the intensity of the fire. The authors sampled all stems with a stem diameter of more than $2 \mathrm{~cm}$, which included many shrubs found in the undergrowth under the trees. The Campo sujo also has a continuous grass stratum (Ribeiro \& Walter 2008), which may contribute to an increase in the intensity of fires.

Despite this variation among physiognomies in the response to fire damage, comparisons among sites indicate that species tend to present similar patterns of response, even in different regions (Hoffmann \& Solbrig 2003; Miranda \& Sato 2005). In Campo sujo for example, Medeiros \& Miranda (2008) assessed the response to fire in nine of the species investigated in the present study. In seven of these species (D. elliptica, O. hexasperma, $Q$. grandiflora, Q. parviflora, B. coccolobifolia, B. pachyphylla and $H$. byrsonimifolia), more than $50 \%$ of individuals presented an epigeal or epigeal + hypogeal response in both studies. Similarly, more than $70 \%$ of the $R$. montana in both studies presented a hypogeal response or mortality. Only in the case of E. suberosum were more pronounced differences found between studies. In the present study, $58 \%$ of the individuals of this species presented hypogeal resprouting, as against only $22 \%$ in the study of Medeiros \& Miranda (2008). These comparisons indicate that the specific adaptations of a species are the principal determinants of their capacity to respond to fire damage, irrespective of differences in the location of individuals, the physiognomies they inhabit or the intensity of the fire.

Bark thickness and stem diameter were the most important determinants of the type of response of an individual to fire damage. Bark thickness was the most important factor, as observed in previous studies, which indicate that savanna vegetation impacted frequently by fires tends to select species with thicker bark (Dantas \& Pausas 2013). The thickness of the bark determines its capacity for thermal insulation, which protects vital stem tissues from flames and high temperatures (Hoffmann \&
Solbrig 2003; Miranda \& Sato 2005; Pausas 2014). During fires, individuals with thinner bark are more vulnerable to damage to the phloem, leading to a reduction in the efficiency of sap flow, which impacts the growth of the tree and will eventually provoke its death (Taiz \& Zeiger 2004). Thick bark may thus be vital to the survival of trees in Brazilian savannas subject to frequent fire damage (Miranda et al. 2010; Pausas 2014), which will, in turn, determine the structure and species composition of local plant communities (Moreira et al. 2008).

A number of previous studies have also identified tree height as an important determinant of the type of response of trees to fire damage in Brazilian savannas, this study contradicts previous studies. For example, Medeiros \& Miranda (2005) concluded that tree height is an important predictor of the severity of fire damage, with individuals shorter than $1.5 \mathrm{~m}$ being more prone to top-kill, and having only hypogeal resprouts. Miranda et al. (1993) also defined a height of $0.6 \mathrm{~m}$ as the minimum necessary to guarantee survival of a fire. By contrast, the findings of our study indicated that bark thickness and stem diameter were the principal predictors of the type of resprouting, and that the inclusion of tree height in the analysis did not increase its predictive power. Similar findings have been obtained in comparative studies of the fire survival strategies of the vegetation of African and South American savannas (Dantas \& Pausas 2013; Pausas 2014). Lawes \& Clarke (2011) for example, showed that tree survival was correlated exclusively with bark thickness, rather than stem height or diameter. In this case, tree height may only have an indirect influence on the type of response to fire damage, through its positive relationship with other variables, such as bark thickness and stem diameter.

\section{Conclusions}

In the present study of the Cerrado sensu stricto, the fire damage was relatively mild, considering the low mortality and high rates of epigeal resprouting. Comparing these results with previous studies, we observed considerable variation in the contribution of the different patterns of resprouting in the various types of vegetation found in the Brazilian savanna. Even so, species tend to present a standard response to fire damage, irrespective of the environment or possible difference in the fire intensity. The thickness of the bark is the most important determinant of the type of response of a woody plant to fire damage. This means that species with thick bark may present similar resprouting patterns, whatever the vegetation type. By improving the knowledge of how tree species are adapted to fire, our results contribute to improve assessments of vulnerability of the Cerrado vegetation to this disturbance and to better predict the impact of changes in the fire regime. 


\section{Acknowledgements}

This study was supported by a master fellowship from the Brazilian federal government to F. Souchie (CAPES/ $\mathrm{DS})$ and one postdoctoral fellowship to D Silvério (CNPq, PDJ:50322/2016-0).

\section{References}

Bellingham PJ, Sparrow AD. 2000. Resprouting as a life history strategy in woody plant communities. Oikos 89: 409-416.

Bond W, Midgley J. 2001. Ecology of sprouting in woody plants: the persistence niche. Trends in Ecology \& Evolution 16: 45-51.

Bowman DMJS, Balch JK, Artaxo P, et al. 2009. Fire in the earth system. Science 324: 481-484.

Charles-Dominique T, Beckett H, Midgley GF, Bond WJ. 2015. Bud protection: a key trait for species sorting in a forest-savanna mosaic. New Phytologist 207: 1052-1060.

Cirne P, Miranda HS. 2008. Effects of prescribed fires on the survival and release of seeds of Kielmeyera coriacea (Spr.) Mart. (Clusiaceae) in savannas of Central Brazil. Brazilian Journal of Plant Physiology 20: 93-8.

Clarke PJ, Lawes MJ, Midgley JJ, et al. 2013. Resprouting as a key functional trait: how buds, protection and resources drive persistence after fire. New Phytologist 197: 19-35.

Coutinho LM. 1990. Fire in the ecology of the Brazilian cerrado. In: Goldammer JG. (ed.) Fire in the tropical biota: Ecosystem processes and global challenges. Berlin: Springer Verlag. p. 82-105.

Dantas VL, Pausas JG. 2013. The lanky and the corky: Fire-escape strategies in savanna woody species. Journal of Ecology 101: 1265-1272.

Felfili JM, Carvalho FA, Haidar RF. 2005. Manual para o Monitoramento de parcelas permanentes nos biomas Cerrado e Pantanal. Brasília, Biblioteca Central da Universidade de Brasília.

Gomes L, Lenza E, Maracahipes L, Schwantes B, Almeida E. 2011. Comparações florísticas e estruturais entre duas comunidades lenhosas de cerrado típico e cerrado rupestre Mato Grosso, Brasil. Acta Botanica Brasilica 25: 865-875.

Hoffmann WA, Adasme R, Haridasan M, et al. 2009. Tree topkill, not mortality, governs the dynamics of savanna-forest boundaries under frequent fire in central Brazil. Ecology 90: 1326-1337.

Hoffmann WA, Solbrig OT. 2003. The role of topkill in the differential response of savanna woody species to fire. Forest Ecology and Management 180: 273-286.

Hoffmann WA, Franco AC. 2003. Comparative growth analysis of tropical forest and savanna woody plants using phylogenetically independent contrasts. Journal of Ecology 91: 475-484.

Hoffmann WA, Orthen B, Franco AC. 2004. Constraints to seedling success of savanna and forest trees across the savanna-forest boundary. Oecologia 140: 252-60.

Keeley JE, Pausas JG, Rundel PW, Bond WJ, Bradstock RA. 2011. Fire as an evolutionary pressure shaping plant traits. Trends in Plant Science 16: 406-411.

Lawes MJ, Clarke PJ. 2011. Ecology of plant resprouting: populations to community responses in fire-prone ecosystems. Plant Ecology 212: 1937-1943.

Lehmann CER, Anderson TM, Sankaran M, et al. 2014. Savanna VegetationFire-Climate Relationships Differ Among Continents. Science 343: 548-553.

Marimon-Junior BH, Haridasan M. 2005. Comparação da vegetação arbórea e características edáficas de um cerradão e um cerrado sensu stricto em áreas adjacentes sobre solo distrófico no leste de Mato Grosso , Brasil. Acta Botanica Brasilica 19: 913-926.

Medeiros MB, Miranda HS. 2008. Post-Fire Resprouting and mortality in Cerrado woody plant species over a three-year period. Edinburgh Journal of Botany 65: 53-68.

Medeiros MB, Miranda S. 2005. Mortalidade pós-fogo em espécies lenhosas de campo sujo submetido a três queimadas prescritas anuais. Ecology 19: $493-500$

Miranda AC, Miranda HS, Dias IFO, Dias BFS. 1993. Soil and air temperatures during prescribed cerrado fires in Central Brazil. Journal of Tropical Ecology 9: 313-320

Miranda HS, Bustamante MMC, Miranda AC. 2002. The fire factor. In: Oliveira PS, Marquis RS. (eds.) The Cerrados of Brazil: Ecology and natural history of a neotropical savanna. New York, The University of Columbia Press. p. 51-68.

Miranda HS, Neto WN, Neves BMC. 2010. Caracterização das queimadas de Cerrado. In: Miranda HS. (ed.) Efeitos do regime de fogo sobre a estrutura de comunidades de Cerrado: projeto fogo. Brasília, Ibama. p. 23-33.

Miranda HS, Sato MN. 2005. Efeitos do fogo na vegetação lenhosa do Cerrado. In: Scariot A, Sousa-Silva JC, Felfili J. (eds.) Cerrado: ecologia, biodiversidade e conservação. Brasília, MMA. p. 93-105.

Miranda HS, Sato MN, Neto WN, Aires FS. 2009. Fires in the cerrado, the Brazilian savanna. In: Cochrane M. (ed.) Tropical Fire ecology: climate change. land use and ecossystem dynamics. Berlin Heidelberg, Springer. p. 427-450.

Mistry J. 1998. Fire in the cerrado (savannas) of Brazil: an ecological review. Progress in Physical Geography 22: 425-448.

Moreira F, Catry F, Duarte I, Acácio V, Silva JS. 2008. A conceptual model of sprouting responses in relation to fire damage: an example with cork oak (Quercus suber L.) trees in Southern Portugal. Plant Ecology 201: 77-85.

Moreira F, Duarte I, Catry F, Acácio V. 2007. Cork extraction as a key factor determining post-fire cork oak survival in a mountain region of southern Portugal. Forest Ecology and Management 253: 30-37.

Oliveira RS, Bezerra L, Davidson EA, et al. 2005. Deep root function in soil water dynamics in cerrado savannas of central Brazil. Functional Ecology 19: 574-581.

Pausas JG. 2014. Bark thickness and fire regime. Functional Ecology 29: 315-327.

R Core Team. 2016. R: A language and environment for statistical computing. Vienna, R Foundation for Statistical Computing. https:// www.R-project.org/.

RADAMBRASIL. 1981. Levantamento de recursos naturais. folha SD- 22/ Goiás. Rio de Janeiro, Ministério das Minas e Energia.

Ribeiro JF, Walter BMT. 2008. As principais fitofisionomias do bioma Cerrado. In: Sano SM, Almeida SP, Ribeiro JF. (eds.) Cerrado: ecologia e flora. Planaltina, Embrapa - Cerrados. p. 151-199.

Ribeiro MN, Sanchez M, Pedroni F, Peixoto KS. 2012. Fogo e dinâmica da comunidade lenhosa em cerrado sentido restrito, Barra do Garças, Mato Grosso. Acta Botanica Brasilica 26: 203-217.

Sartorelli PAR, Silva JMS, Gorenstein MR, Gomes JE, Ávila EQ. 2007. Rebrota após fogo de espécies arbóreas de diferentes grupos fenológicos foliares em cerrado stricto sensu. Revista Científica Eletronica de Engenharia Florestal 6: 1-13.

Sato MN, Miranda HS, Maia JMF. 2010. O fogo e o estrato arbóreo do Cerrado: efeitos imediatos e a longo prazo. In: Miranda HS. (ed.) Efeitos do regime de fogo sobre a estrutura de comunidades de Cerrado: projeto fogo. Brasília, Ibama. p. 77-91.

Silva FAM, Assad ED, Evangelista BA. 2008. Caracterização climática do bioma Cerrado. In: Sano SM, Almeida SP. (eds.) Cerrado: ambiente e flora. Planaltina, Embrapa - Cerrados. p. 68-88.

Silvério DV, Pereira OR, Mews HA, Maracahipes-Santos L, Santos JO, Lenza E. 2015 Surface fire drives short-term changes in the vegetative phenology of woody species in a Brazilian savanna Biota Neotropica 15: http://dx.doi.org/10.1590/1676-0611-BN-2014-0077.

Taiz L, Zeiger E. 2004. Fisiologia Vegetal. 3rd edn. Porto Alegre, Artmed Editora.

Vale VS, Lopes SF. 2010. Efeitos do fogo na estrutura populacional de quatro espécies de plantas do Cerrado. Revista Nordestina de Biologia 19: 45-53.

Zar JH. 2010. Análise biostatistical. 5th edn. Upper Saddle River, Pearson Prentice-Hall.

Zuur AF, Ieno EN, Walker NJ, Saveliev AA, Smith GM. 2009. Mixed effects models and extensions in ecology with R. New York, Springer-Verlag. 